\title{
What can be done about the dearth of information for local decision-making? \\ An analysis from the design of a territorial development index based on administrative records
}

\author{
Ismael Toloza, Sergio Sánchez and Javier Carrasco ${ }^{1}$
}

\section{Abstract}

This article addresses the issue of information availability for decision-making at the subregional level. It proposes the construction of a territorial development index (TDI) based on administrative records and comprising 19 variables grouped into 6 dimensions: (i) cultural capital, (ii) social capital, (iii) human capital, (iv) institutional capital, (v) tangible capital and (vi) economic capital. The approach underlying the proposed model centres on territorial development and the structural factors determining it. The variables making up the TDI were selected in consultation with experts and with the use of multivariate statistical analyses. This paper sets out to document many of the phases, procedures and decisions leading to the TDI, as a way of opening up the discussion around this line of research. It concludes by presenting calculations of the TDI for the Chilean municipalities of Angol and Carahue.

\section{Keywords}

Local government, decision-making, information, information access, regional development, development indicators, multivariate analysis, Chile

JEL classification

018

\section{Authors}

Ismael Toloza holds a PhD in economics from the National Autonomous University of Mexico and is a researcher, academic and coordinator with the Programme for Territorial Development and Competitiveness of the Institute of Local and Regional Development (IDER) at the University of the Frontier (Chile). Email: ismael.toloza@ufrontera.cl.

Sergio Sánchez holds an MA in Social Research Methodology from Complutense University of Madrid and is a researcher with IDER at the University of the Frontier (Chile). Email: sergio.sanchez@ufrontera.cl.

Javier Carrasco holds an MA in Statistics from the University of Concepción (Chile) and heads the Statistical Infrastructure Unit of the National Institute of Statistics in the Araucanía region (Chile). Email: javier.carrasco@ine.cl. 


\section{Introduction}

Chile lacks robust information for local decision-making. ${ }^{2}$ It was with this assertion that the Outlying Areas Committee of the Chilean Senate opened its session of 6 June 2016.

The way development at all levels (national, regional, territorial and local) is understood has transitioned from approaches concentrating almost exclusively on economic growth towards models of multidimensional, holistic interpretation. On this view, the ability to trigger development processes depends on considerations that yield an understanding of the factors determining these processes and the public or private policy and management decisions that subsequently affect them. This understanding becomes more difficult as the observer delves deeper into the subnational scale and is able to obtain less and less information and data because of a lack of robust periodic series, or finds that such series as do exist, e.g., the National Socioeconomic Survey (CASEN) and the New National Employment Survey (NENE), are unrepresentative. In these circumstances, information presented in a format that describes the development and competitiveness indicators available for the interpretation of phenomena and for decision-making at the local level usually comes from a mix of sources. This means that the secondary information available needs to be reinforced or supplemented with primary information gathered through surveys or interviews. This process adds to the cost of obtaining indicators, so that the scope for reproducing them is limited or dependent on the availability of resources.

This dearth of information for decision-making at the territorial and local level has become a limitation and a challenge for the country. The situation was acknowledged in the report of the Presidential Advisory Committee for Decentralization and Regional Development (2014), which points to a need to create integrated regional systems of territorial information for decision-making, since while plentiful data are available in municipal or sectoral administrative records at the local and territorial level, it is important to determine their availability and reliability. There also needs to be a restructuring to enable data to be better exploited and provide more and better information for subnational public and private policymaking in a way that is more relevant to each territory's complexity and specificity. The growing demand for local and commune-level statistics is a concern that has been addressed since 2011 by the Social Observatory of the Ministry of Social Development (MIDESO), together with the office of the United Nations Development Programme (UNDP) in Chile. In this framework, thought has been put into the development of a methodology for estimating small areas from the data of the 2009 CASEN survey that can be reapplied in subsequent versions (Ministry of Social Development, 2013).

Against this background, the present article aims to make a contribution in at least two areas. First, it seeks to help remedy local information deficiencies by presenting a design for a territorial development index (TDI) constructed exclusively from information in administrative records. Second, it posits an approach to territorial development centred on identification of the structural factors that, as Boisier (2004) argues, are critical to the systemic emergence of development.

With these ends in view, a theoretical framework based on the structural development factors approach was created to provide the underpinnings for the design of the indicator. Currently available subnational indicators applying a territorial approach were reviewed. The TDI was then designed on the basis of the composite index construction methodology laid out in the Handbook on Constructing Composite Indicators: Methodology and User Guide published by the Organization for Economic Cooperation and Development (OECD, 2008) and in "Guía metodológica: diseño de indicadores compuestos de desarrollo sostenible" (Schuschny and Soto, 2009). The indicator was tested (i.e., calculated) in Carahue and Angol, two communes in the Araucanía region.

\footnotetext{
2 As Filgueira (2006) puts it, this means the transformation of data into indicators and of these into information providing a means to greater social intelligence and knowledge (evolutionary pyramid of the incorporation of technical knowledge into public policy).
} 


\section{Theoretical framework}

\section{Territorial development and dynamics}

As Alburquerque (2013) has noted, the old sectoral polices that used to define the central administration of the State have been giving way to policies designed with a territorial approach. This is because a position needs to be taken in the different local spheres on substantive development issues (e.g., production innovations, human resources and environmental sustainability). In this context, Vázquez Barquero (2007) argues that the development of a territory consists in a process of endogenous changes and transformations driven by the creativity and entrepreneurial capacity already present there. Accordingly, development processes cannot be explained by external mechanisms alone. These processes usually arise endogenously, putting territories' capacities to work by way of the mechanisms and forces that characterize capital accumulation and facilitate economic and social progress.

This particular approach to development seeks to explain how dynamics operate, are manifested, interact and evolve in a given territorial space. This is consistent with the statement by the United Nations Economic and Social Council (2011) that sustaining well-being depends on our ability to ensure that capital stocks (natural, tangible, human and social capital) are passed on to future generations.

In this context, and from the standpoint of complexity theory, Boisier (2004) understands the structure and dynamics of development as the emergence of a complex territorial system. Within this, it is possible to identify subsystems that, in turn, are comprised of more specific elements. Table 1 describes the six subsystems established by Boisier.

Table 1

Boisier's subsystems

\begin{tabular}{|c|c|}
\hline (i) Axiological subsystem & $\begin{array}{l}\text { A set of universal and singular values that define what it is to belong to a particular territory } \\
\text { and that distinguish it from other territories. }\end{array}$ \\
\hline (ii) Accumulation subsystem & $\begin{array}{l}\text { Includes the accumulation of capital, technical progress and human capital, which are factors in the current } \\
\text { theorization of endogenous growth. In the exogeneity of development it is possible to identify the importance } \\
\text { of these factors with regard to territory, national political projects, general and sectoral economic policy and } \\
\text { external demand (given the greater degree of openness). This makes it necessary to reconsider how public } \\
\text { policy is made at the meso (regional) level, while institutions at the subnational level (region, province, } \\
\text { commune) could play a proactive role in making these decisions more endogenous. }\end{array}$ \\
\hline (iii) Decision-making subsystem & $\begin{array}{l}\text { Configured by individual, corporate and collective agents, this is the human expression of the territory. Thus, } \\
\text { it is not enough to identify and list all agents. What is necessary, rather, is to accurately identify the projects } \\
\text { pursued by each, since disparate visions will have to be reconciled when a political project for development } \\
\text { (a territorial development plan, for instance) comes to be settled on. }\end{array}$ \\
\hline (iv) Organizational subsystem & $\begin{array}{l}\text { This comprises the universe of public and private organizations in the territory. As with the previous } \\
\text { dimension, what needs determining is not just the organizational map and its density, but the levels } \\
\text { of interrelationship, linkage and synergy of its actions. }\end{array}$ \\
\hline (v) Procedural subsystem & $\begin{array}{l}\text { This refers to the procedures of the public administration in the territory for service provision, information flow } \\
\text { management and actions in support of the territory to optimize its positioning in globalization (opportunities). } \\
\text { The entropic (disorderly) characteristics of public information, which increase transaction costs and } \\
\text { uncertainty and so act as a hindrance to economic growth, are recognized here. }\end{array}$ \\
\hline (vi) Subliminal subsystem & $\begin{array}{l}\text { Configured by nine categories of intangible capital, namely cognitive, symbolic, cultural, social, civic, } \\
\text { institutional, psychosocial, media and human capital, which are considered key factors in development when } \\
\text { this is likewise conceived of as an intangible outcome. }\end{array}$ \\
\hline
\end{tabular}

Source:S. Boisier, "Una (re)visión heterodoxa del desarrollo (territorial): un imperativo categórico", Estudios Sociales, vol. 12, No. 23, January-June 2004 [online] https://dialnet.unirioja.es/descarga/articulo/2108278.pdf.

There needs to be the greatest possible level of interconnection between these six subsystems, this being what is referred to by the concepts of "neuronal synapsis" and "neuronal synchrony". Without high-density synapses, development cannot arise (Toloza, 2007). 
From another point of view, the methodological guide "Marco conceptual, metodológico y operativo de la planificación regional” (González, Sánchez and Araúz, 2011) produced by the Ministry of National Planning and Economic Policy (MIDEPLAN) of Costa Rica and UNDP indicates that the territorial development approach encompasses the dimensions described in table 2.

Table 2

Dimensions according to the United Nations Development Programme

\begin{tabular}{|c|c|}
\hline (i) Economic and production dimension & $\begin{array}{l}\text { This is associated with decisions and activities affecting the capacity for wealth creation with } \\
\text { a territorial connection on the basis of the set of modalities of existing production systems and } \\
\text { distribution structures for wealth produced at the territorial level. Dimensions such as investment, } \\
\text { the quality and relevance of human capital formation, social capital, productivity, the generation of } \\
\text { knowledge and innovation and popular knowledge also need to be taken into account, as they feed } \\
\text { through into competitiveness and, especially, into economic inclusion and justice. }\end{array}$ \\
\hline (ii) Social dimension & $\begin{array}{l}\text { Described as the aspirations and needs of the population belonging to a territory, in the light of its } \\
\text { diversity and socioeconomic, ethnic, cultural and age characteristics. In this dimension, inclusion, } \\
\text { equity, respect for diversity and social responsibility need to be assured. }\end{array}$ \\
\hline (iii) Environmental dimension & $\begin{array}{l}\text { This is connected to the principles and strategies of sustainable development and environmental } \\
\text { security and encompasses a very wide range of issues, such as care for life, bad social practices that } \\
\text { increase the risks associated with climate change, pollution, socioenvironmental risk, salinization } \\
\text { of underground reserves, waste management and species predation. }\end{array}$ \\
\hline (iv) Cultural dimension & $\begin{array}{l}\text { Territories differ from one another and are also socially heterogeneous internally, and this has a } \\
\text { cultural manifestation. There are different elements of identity that can generate conflict and risk } \\
\text { if not addressed in all their complexity and importance. This differentiation can also turn into } \\
\text { inequality and exclusion if differences are not properly understood and addressed, something that is } \\
\text { manifested in forms of organization, world views and production methods, among other things. }\end{array}$ \\
\hline (v) Political and institutional dimension & $\begin{array}{l}\text { Territorial development should be deliberately managed, which means creating scenarios, agendas } \\
\text { and strategic roadmaps. It also requires institutional arrangements that give rise to policies, strategies } \\
\text { and mechanisms for implementation, oversight and follow-up of actions in the short, medium and } \\
\text { long run. All this should take place in a context of dialogue and consensus. Arriving at shared visions, } \\
\text { priorities, agreements, responsibilities and areas of coordination requires institutions that can make } \\
\text { the proposed strategic design work in practice. For this, it is necessary to ensure that the material, } \\
\text { human, cultural and heritage resources available are used to support territorial development. }\end{array}$ \\
\hline
\end{tabular}

Source:H. González, O. M. Sánchez and Y. Araúz, "Marco conceptual, metodológico y operativo de la planificación regional: guía metodológica para el diseño de la estrategia de abordaje regional en planificación del desarrollo", Ministry of National Planning and Economic Policy/United Nations Development Programme (UNDP), 2011 [online] https:// documentos.mideplan.go.cr/alfresco/d/d/workspace/SpacesStore/8c656860-8f17-47df-a6e1-67cfccf89dff/CPR001_1.pdf?guest=true.

Accordingly, territorial development is conceived on the basis of a set of elements that enable it to be defined as a multidetermined yet comprehensive theoretical concept taking account of the economic and production, social, environmental, cultural and political and institutional aspects (González, Sánchez and Araúz, 2011).

Requejo (2007) develops a similar perspective from a structure based on five types of capital: natural, tangible-constructed, human, social and image capital (see table 3).

Table 3

Types of capital according to Requejo

\begin{tabular}{ll}
\hline (i) Natural capital & $\begin{array}{l}\text { The reserve of goods furnished by the environment (land, forests, water, wetlands, etc.) that provide } \\
\text { the territory with particular goods and services. }\end{array}$ \\
\hline (ii) Tangible-constructed capital & $\begin{array}{l}\text { Basic infrastructure, residential buildings, public equipment, production facilities and installations of any other } \\
\text { kind, and equipment associated with production, public services and consumption in a territory. }\end{array}$ \\
\hline (iii) Human capital & $\begin{array}{l}\text { The population's ability to undertake production processes and attain higher levels of well-being and quality } \\
\text { of life through the use of knowledge, capabilities and aptitudes. }\end{array}$ \\
\hline (iv) Social capital & A society's ability to respond effectively to its needs and organize itself in order to adapt. \\
\hline (v) Image capital & Recognition of the value associated with a territory's identity.
\end{tabular}

Source:J. Requejo, "Clases de capital territorial. Clases de capital territorial y desarrollo sostenible", 2007 [online] http://www. atclave.es/publicaciones/descargas/pub_desarrollo/17_clases_de_capital_territorial.pdf. 
Analysis of the first part of the methodological guide to territorial economic development titled Proposiciones para el proceso de construcción y realización de una estrategia de desarrollo económico territorial (Chile Emprende, 2005) shows that decentralized management models with a territorial approach (commonly known as territorial development models) are structured on the basis of a multidimensional vision of development that recognizes the existence of different types of territorial capital. These are the whole range of natural, economic, human, institutional and cultural resources that give a territory its identity and special character, influence its competitiveness and represent its endogenous development potential. As with any form of capital, these are not fixed reserves of resources, since part of their essence is their potential to reproduce and expand.

The theoretical framework for territorial capital proposed by Chile Emprende (2005) refers to five dimensions (or types of capital): (i) corporate and labour competitiveness, (ii) tangible capital and land use planning, (iii) institutional capital, (iv) social capital and (v) identity and culture. Table 4 presents these concepts, supplemented and adapted for the purposes of the present design.

Table 4

Types of capital according to Chile Emprende

\begin{tabular}{ll}
\hline (i) Human capital & $\begin{array}{l}\text { The critical mass of human resources in business, the workforce and academia, people with leadership } \\
\text { capacities and their level of competitiveness and development. }\end{array}$ \\
\hline (ii) Financial capital & $\begin{array}{l}\text { Investments, capital availability, the supply of financing, intermediation instruments, borrowing capacity } \\
\text { and financial institutions in the territory. }\end{array}$ \\
\hline (iii) Tangible and natural capital & $\begin{array}{l}\text { Land use planning to provide the infrastructure needed for development opportunities to be pursued, } \\
\text { and also the territory's natural capital and the way it connects to these opportunities. }\end{array}$ \\
\hline (iv) Institutional capital & $\begin{array}{l}\text { The soundness of institutions in the territory, be they public or private, and standards, laws, programmes } \\
\text { and service platforms, among other things. }\end{array}$ \\
\hline (v) Social capital & $\begin{array}{l}\text { For the purposes of this theoretical model, this means community social capital and the existence } \\
\text { of networks, organizational management and cooperation assets, conflicts and the history of conflicts. }\end{array}$ \\
\hline (vi) Symbolic capital & A territory's identity and culture, tacit knowledge and traditional lore, among other things. \\
\hline
\end{tabular}

Source:Chile Emprende, Guía metodológica del desarrollo territorial, Santiago, 2005 [online] http://www.dhl.hegoa.ehu.es/ ficheros/0000/0243/Chile_Estrategia_de_desarrollo_econ\%C3\%B3mico_territorial_2009.pdf.

In this context, and from the point of view of territorial development, it is important to be clear about the dimensions of territorial capital that need to be brought into play to capture opportunities and determine the level of relative development currently exhibited by these dimensions. This is a way of attempting to establish which divides and variables might best be dynamized in order to exploit or capture development opportunities in a territory (Chile Emprende, 2005).

Thus, implementing development processes from the perspective of decentralized management models with a territorial approach requires an ongoing effort to accumulate these types of territorial capital. The trigger for the systemic emergence of a territory, on this view, is the pursuit of processes (policies, programmes, projects and actions) aimed at increasing territorial capital inflows while reducing outflows, in order to create a permanent accumulation dynamic.

For the purposes of this study, these last theories based on the six types of territorial capital as structural factors in development are the ones that make the most sense when it comes to constructing a territorial development indicator.

\section{Methodology}

The methodology was based on the Handbook on Constructing Composite Indicators: Methodology and User Guide published by OECD (2008) and on "Guía metodológica: diseño de indicadores compuestos de desarrollo sostenible", the methodology guide for designing composite sustainable development indicators prepared by Schuschny and Soto (2009). 
First, setting out from the definition of the types of territorial capital described in the theoretical framework above, the following dimensions of the TDI were defined: symbolic or cultural capital, human capital, social capital, institutional capital, tangible and infrastructure capital and economic capital. It was decided that the pilot communes for estimating the indicator would be Carahue and Angol. ${ }^{3}$

In an initial phase, the working methodology used to construct the TDI was based on workshops, debates and periodic working meetings in which each of the decisions and components making up the model presented here were progressively arrived at.

The first exercise was to form a panel of experts ${ }^{4}$ tasked with drawing up a preliminary list of explanatory variables in each dimension. Accordingly, a first workshop was held and 107 initial variables associated with the dimensions specified were established. Identification of the variables at this stage was mainly based on the thematic coverage criterion, meaning that the variables had to have a direct relationship with the operational definition of the dimension.

\section{First model adjustment}

The 107 variables were put through a filter based on the criterion of data availability in administrative records. This yielded a first adjustment that brought down the number from 107 to 88 (see annex A1).

\section{Second model adjustment}

Setting out from the 88 variables selected in the first adjustment, a second model adjustment was carried out on the basis of three additional criteria: (i) information quality, (ii) periodicity and (iii) representativeness. ${ }^{5}$ In this way, a total of 49 variables were rejected, leaving a somewhat more restricted model with a total of 39 variables, as shown in table 5 .

Table 5

Second identification of dimensions and variables for the territorial development index

\begin{tabular}{|c|c|c|}
\hline Dimension & Variable & Operational definition \\
\hline \multirow[t]{5}{*}{ (i) Cultural capital } & 1. Cultural events & Number of large-scale cultural events per year, by commune. \\
\hline & 2. Tangible cultural heritage & Number of heritage assets recognized by decree, by commune. \\
\hline & 3. Intangible cultural heritage & $\begin{array}{l}\text { Number of intangible heritage assets registered in the Information System } \\
\text { for Heritage Management (SIGPA), by commune. }\end{array}$ \\
\hline & 4. Indigenous communities and associations & Number of indigenous communities and associations, by commune. \\
\hline & 5. Place brands and designations of origin & Number of geographical indications and designations of origin, by commune. \\
\hline (ii) Social capital & 6. Organizations with social aims & $\begin{array}{l}\text { Number of organizations with social aims and current legal personality, } \\
\text { by commune. These include parents' associations, older adult centres } \\
\text { or organizations, sports clubs, neighbourhood committees and other } \\
\text { functional groupings. }\end{array}$ \\
\hline \multirow[t]{4}{*}{ (iii) Human capital } & 7. Years of education & Years of secondary education, by commune. \\
\hline & 8. University selection tests (PSU) & Average PSU scores, by commune. \\
\hline & 9. Economically active population (EAP) & $\begin{array}{l}\text { Percentage of the population that is of working age (employed } \\
\text { and unemployed), by commune. }\end{array}$ \\
\hline & 10. Employability & Percentage of the EAP that is in work, by commune. \\
\hline
\end{tabular}

3 These communes participate in the University is Territory (UNETE) regional performance agreement operated by the University of the Frontier, which facilitates data collection.

4 The members were Ismael Toloza, PhD in Economics; Sergio Muñoz, PhD in Statistics; Javier Carrasco, MA in Statistics; Alejandro Henríquez, engineering manager of the office of the National Institute of Statistics (INE) in the Araucanía region; Sergio Sánchez, MA in Research Methodologies; Camilo Rosas, sociologist and lecturer in Social Statistics; Ana María Alarcón, PhD in Anthropology; and Carlos Pineda, Paula Arias and Patricio Gallardo, professionals with the INE technical unit in the Araucanía region.

5 Namely information quality, meaning the existence of a validated methodology for data generation and recording; periodicity, which concerns the date and frequency with which data are updated; and representativeness, meaning the statistical validity of the data at the communal level. 
Table 5 (concluded)

\begin{tabular}{|c|c|c|}
\hline Dimension & Variable & Operational definition \\
\hline \multirow{6}{*}{$\begin{array}{l}\text { (iv) Institutional } \\
\text { capital }\end{array}$} & 11. Municipal Common Fund (FCM) share & Percentage of total municipal revenue that is from the FCM, by municipality \\
\hline & 12. Municipal revenues & Municipal revenues in millions of Chilean pesos, by municipality. \\
\hline & 13. Municipal spending & Municipal spending per capita in millions of Chilean pesos, by municipality. \\
\hline & $\begin{array}{l}\text { 14. Communal Development Plan } \\
\text { (PLADECO) }\end{array}$ & Existence of a current PLADECO, by municipality. \\
\hline & $\begin{array}{l}\text { 15. Annual Municipal Education Plan } \\
\text { (PADEM) }\end{array}$ & Existence of a current PADEM, by municipality. \\
\hline & 16. Annual Municipal Health Plan (PASAM) & Existence of a current PASAM, by municipality. \\
\hline \multirow{13}{*}{$\begin{array}{l}\text { (v) Tangible and } \\
\text { infrastructure } \\
\text { capital }\end{array}$} & 17. Concrete roads & Kilometres of concrete roads, by commune. \\
\hline & 18. Asphalted roads & Kilometres of asphalted roads, by commune. \\
\hline & 19. Gravel roads & Kilometres of gravel roads, by commune. \\
\hline & 20. Telephone coverage & Percentage fixed-line telephone coverage, by commune. \\
\hline & 21. Internet coverage & Percentage fixed-line Internet coverage, by commune. \\
\hline & 22. Square metres constructed & $\begin{array}{l}\text { Square metres constructed and officially certified per capita during } \\
\text { the year, by commune. }\end{array}$ \\
\hline & 23. Drinking water coverage & Percentage drinking water coverage, by commune. \\
\hline & 24. Sewer system coverage & Percentage coverage of sewer system, by commune. \\
\hline & 25. Electricity grid coverage & Percentage coverage of electricity grid, by commune. \\
\hline & 26. Educational establishments & Number of educational establishments, by commune. \\
\hline & 27. Health-care establishments & Number of health-care establishments, by commune. \\
\hline & 28. State-protected wilderness areas & Square kilometres of protected wilderness areas, by commune. \\
\hline & 29. Native forest & Square kilometres of native forest, by commune. \\
\hline \multirow{9}{*}{$\begin{array}{l}\text { (vi) Economic } \\
\text { capital }\end{array}$} & 30. Microenterprises & Number of microenterprises, by commune. \\
\hline & 31. Workers in microenterprises & Number of workers in microenterprises, by commune. \\
\hline & 32. Small enterprises & Number of small enterprises, by commune. \\
\hline & 33. Workers in small enterprises & Number of workers in small enterprises, by commune. \\
\hline & 34. Medium-sized enterprises & Number of medium-sized enterprises, by commune. \\
\hline & 35. Workers in medium-sized enterprises & Number of workers in medium-sized enterprises, by commune. \\
\hline & 36. Large enterprises & Number of large enterprises, by commune. \\
\hline & 37. Workers in large enterprises & Number of workers in large enterprises, by commune. \\
\hline & 38. Investments & Number of projects being implemented, by commune. \\
\hline (vii) Other variables & 39. Poverty & Percentage incidence of poverty, by commune. \\
\hline
\end{tabular}

Source: Prepared by the authors.

In connection with the above, the document "Indicadores sociales y marcos conceptuales para la medición social" (Cerda and Vera, 2008) describes a number of aspects worth bearing in mind when variables are identified for the design of indices. They include the existence of data, the coverage of geographical areas and data accessibility and comparability.

\section{(a) Consistency analysis}

It was necessary to have analysable data to test the structure and functioning of the model, considering that commune-level data are hard to access. Accordingly, and for analytical purposes, it was considered that the most practical option would be to subject the model to a series of multivariate analyses using region-level data, given that more information is available for variables analysed at that level (see annex A2). According to Hair, Anderson and Tatham (1987), one of the advantages of multivariate techniques is that they provide the ability to analyse a whole set of variables for an object simultaneously, yielding results that could not be obtained with univariate methods.

This analysis serves various purposes. In the first place, it aims to confirm that the model is valid, i.e., that the set of variables selected does actually measure an object associated with territorial development. To this end, correlation and regression analyses were carried out (Cuadras, 2007) on 
the indicator constructed in relation to poverty and development indicators. In the second place, conglomerate analyses were carried out (Figueras, 2001) with a view to understanding how the data for the set of variables were grouped in relation to the cases (in this exercise, the regions). In the third place, principal component factor analyses were carried out (García, Gil and Rodríguez, 2001) for each dimension with a view to analysing the internal structure of the variables and the way these were grouped into particular factors. Factor analysis aimed at reducing dimensions is important in that it provides a way of evaluating, on the basis of particular statistical proofs, which variables are the most suitable for explaining the behaviour of or changes in a particular object and which might be left out of the model. The aim here is to reduce the dimensionality of the set of initial variables, seeking to retain most of the information provided by the variables observed (Cea d'Ancona, 2002).

The SPSS and R-project statistics package was mainly used in the multivariate data analysis. Unlike other programs, which are more oriented towards descriptive analysis, this software provides a number of advanced methods of statistical modelling and multivariate analysis.

\section{(b) Multivariate analysis}

To study the feasibility of summarizing the information and reducing the dimensionality of the polynomial concerned, we first evaluated the relevance of carrying out a factor analysis with extraction using the principal components analysis method and with orthogonal rotation based on the Varimax method. Factor analysis can be used to find combinations of variables from the underlying interrelationships between them. These combinations, called factors, are intended to represent the information contained in the variables in a condensed form. This is achieved by using a smaller number of factors that encapsulate a large part of the information, something that is seen in the percentage variance accumulated by the factors. The principal components method, for its part, can be used to create factors that encompass great variability, reducing the dimension of the data. The Varimax rotation method modifies the representation of the factors, once they have been constructed, to bring out the shares of the variables composing them and make them easier to interpret.

When evaluating the relevance of carrying out a factor analysis, it is necessary to show, for each of the dimensions of the TDI, that the data possess certain characteristics which make its use appropriate. This was done by examining the correlation matrix and determining the degree of interrelationship between the variables being studied. Bartlett's test for sphericity, which indicates whether the observed correlations are significant, was then applied to each dimension. The Kaiser-Meyer-Olkin coefficient, which indicates the extent to which the information contained in these variables can be explained from the other variables, was also calculated. This is appropriate for factor analysis.

Next to be studied were commonalities, which bring out the extent to which the variance of a variable is explained by the factor solution. The rotated factor loadings of the variables were also determined. The analysis carried out for each of the dimensions will now be explained in detail.

\section{i. The cultural dimension}

The cultural dimension is represented by the following variables: cultural events (DC1), intangible cultural heritage (CD2), tangible cultural heritage (DC3), place brands (DC4) and indigenous communities (DC5) (see table 6).

Table 6 shows the correlations between the variables in the cultural dimension. It can be seen that they are strongly related. Thus, for example, the Pearson correlation between cultural events and tangible cultural heritage is statistically significant ( $p$-value $<0.001)$. The same is true of the correlations between the pairing of the intangible cultural heritage and tangible cultural heritage variables, on the one hand, and the intangible cultural heritage and place brands variables, on the other ( $p$-value $<0.05)$. 
Table 6

Correlation matrix for the cultural dimension

\begin{tabular}{lrrrrr}
\hline Variable & DC1 & DC2 & DC3 & DC4 & DC5 \\
\hline DC1 & 1.000 & & & & \\
\hline DC2 & 0.420 & 1.000 & & & \\
\hline DC3 & $0.967^{\star \star \star}$ & $0.454^{\star \star}$ & 1.000 & 1.000 & \\
\hline DC4 & 0.398 & 0.400 & $0.456^{\star *}$ & 0.037 & 1.000 \\
\hline DC5 & -0.078 & 0.303 & -0.018 & & \\
\hline
\end{tabular}

Source: Prepared by the authors.

Note: ${ }^{*} p$-value $<0.01 ;{ }^{* \star} p$-value $<0.05 ;{ }^{* *} p$-value $<0.001$.

Bartlett's test for sphericity proved significant (sig. $<0.001$ ), which indicates that there are major correlations and thus that it is worth continuing with the analysis. At the same time, the Kaiser-Meyer-Olkin coefficient within the cultural dimension is about 0.6, meaning that factor analysis is not inadvisable (see table 7).

Table 7

Bartlett's proof of sphericity and the Kaiser-Meyer-Olkin coefficient (cultural dimension)

\begin{tabular}{llr}
\hline Kaiser-Meyer-Olkin measure of sampling adequacy & 0.598 \\
\hline Bartlett's test for sphericity & Approximate chi-squared & 40.149 \\
\cline { 2 - 3 } & gl & 10 \\
\cline { 2 - 3 } & Sig. & 0.000 \\
\hline
\end{tabular}

Source: Prepared by the authors.

The conclusion from all these analyses is that it is appropriate to apply factor analysis to this data series. Accordingly, three factors were selected, accounting between them for $89.714 \%$ of the total variance. The first factor accounts for $51.960 \%$ of the total variance, the second for $23.757 \%$ and the third for $13.997 \%$ (see table 8).

Table 8

Explained variance (cultural dimension)

\begin{tabular}{|c|c|c|c|c|c|c|}
\hline \multirow[b]{2}{*}{ Component } & \multicolumn{3}{|c|}{ Initial eigenvalues } & \multicolumn{3}{|c|}{ Sum of squared saturations of rotation } \\
\hline & Total & $\begin{array}{l}\text { Percentage } \\
\text { variance }\end{array}$ & $\begin{array}{l}\text { Cumulative } \\
\text { percentage }\end{array}$ & Total & $\begin{array}{c}\text { Percentage } \\
\text { variance }\end{array}$ & $\begin{array}{l}\text { Cumulative } \\
\text { percentage }\end{array}$ \\
\hline 1 & 2.598 & 51.960 & 51.960 & 2.598 & 51.960 & 51.960 \\
\hline 2 & 1.188 & 23.757 & 75.717 & 1.188 & 23.757 & 75.717 \\
\hline 3 & 0.700 & 13.997 & 89.714 & 0.700 & 13.997 & 89.714 \\
\hline 4 & 0.485 & 9.705 & 99.419 & & & \\
\hline 5 & 0.029 & 0.581 & 100.000 & & & \\
\hline
\end{tabular}

Source: Prepared by the authors.

Lastly, analysis of the rotated component matrix shows that the cultural events and tangible cultural heritage variables alter in the same direction and are grouped into the first component (some might be left out of the polynomial). The intangible cultural heritage variable is not grouped into any component, meaning that it provides information which cannot be summarized in any linear combination of the other variables. The value of the commonalities, which exceeded $69.0 \%$, should also be emphasized (see table 9). 
Table 9

Rotated component matrix and commonalities (cultural dimension)

\begin{tabular}{lcccc}
\hline Rotated component matrix & \multicolumn{2}{c}{ Commonality } \\
\cline { 2 - 4 } Variable & \multicolumn{1}{c}{ Compont } & & \\
\cline { 2 - 4 } & 0.973 & 2 & 0.173 & 0.977 \\
\hline DC1 & 0.415 & -0.015 & 0.443 & 0.695 \\
\hline DC2 & 0.956 & 0.040 & 0.232 & 0.969 \\
\hline DC4 & 0.218 & 0.020 & 0.950 & 0.950 \\
\hline DC5 & -0.091 & 0.940 & -0.037 & 0.892 \\
\hline
\end{tabular}

Source: Prepared by the authors.

\section{ii. The human capital dimension}

The human capital dimension is constituted at this stage by the following variables: years of education (DE1), average score in university selection tests (PSU) (DE2), labour force participation rate (DE3), employment rate (DE4), regional revenues (DE5) and regional expenditure (DE6).

As regards correlations, there is a strong relationship between the labour force participation rate and the employment rate and a correlation between regional revenues and expenditure (p-value < 0.01) (see table 10).

Table 10

Correlation matrix for the human capital dimension

\begin{tabular}{lrrrrrr}
\hline Variable & DE1 & DE2 & DE3 & DE4 & DE5 & DE6 \\
\hline DE1 & 1.000 & & & & & \\
\hline DE2 & 0.058 & 1.000 & & & & \\
\hline DE3 & $0.552^{\star \star}$ & 0.316 & 1.000 & & & \\
\hline DE4 & $0.557^{\star *}$ & 0.302 & $0.915^{\star \star *}$ & 1.000 & & \\
\hline DE5 & 0.382 & $0.747^{\star * *}$ & 0.290 & 0.299 & 1.000 & 1.000 \\
\hline DE6 & 0.383 & $0.750^{* \star *}$ & 0.298 & 0.307 & $0.999^{\star \star *}$ & \\
\hline
\end{tabular}

Source: Prepared by the authors.

Note: $\quad{ }^{*} p$-value $<0.01 ;{ }^{* \star} p$-value $<0.05 ;{ }^{* \star *} p$-value $<0.001$.

Similarly, Bartlett's test for sphericity proved significant (sig. < 0.001), while the Kaiser-Meyer-Olkin index within the dimension was 0.673 , making it relevant to carry out the factor analysis (see table 11).

Table 11

Bartlett's test for sphericity and the Kaiser-Meyer-Olkin test (human capital dimension)

\begin{tabular}{llc}
\hline Kaiser-Meyer-Olkin measure of sampling adequacy & 0.673 \\
\hline Bartlett's test for sphericity & Approximate chi-squared & 127.581 \\
\cline { 2 - 3 } & gl & 15 \\
\cline { 2 - 3 } & Sig. & 0.000 \\
\hline
\end{tabular}

Source: Prepared by the authors.

In this dimension, three factors accounting for $95.602 \%$ of the total variability of the dimension were selected. The first represents $56.922 \%$ of total variance, the second $27.080 \%$ and the third $11.601 \%$ (see table 12). 
Table 12

Explained variance (human capital)

\begin{tabular}{|c|c|c|c|c|c|c|}
\hline \multirow[b]{2}{*}{ Component } & \multicolumn{3}{|c|}{ Initial eigenvalues } & \multicolumn{3}{|c|}{ Sum of squared saturations of rotation } \\
\hline & Total & $\begin{array}{c}\text { Percentage } \\
\text { variance }\end{array}$ & $\begin{array}{l}\text { Cumulative } \\
\text { percentage }\end{array}$ & Total & $\begin{array}{c}\text { Percentage } \\
\text { variance }\end{array}$ & $\begin{array}{l}\text { Cumulative } \\
\text { percentage }\end{array}$ \\
\hline 1 & 3.415 & 56.922 & 56.922 & 3.415 & 56.922 & 56.922 \\
\hline 2 & 1.625 & 27.080 & 84.002 & 1.625 & 27.080 & 84.002 \\
\hline 3 & 0.696 & 11.601 & 95.602 & 0.696 & 11.601 & 95.602 \\
\hline 4 & 0.180 & 2.993 & 98.595 & & & \\
\hline 5 & 0.084 & 1.402 & 99.997 & & & \\
\hline 6 & 0.000 & 0.003 & 100.000 & & & \\
\hline
\end{tabular}

Source: Prepared by the authors.

The results of the rotation show that the average PSU score, regional revenues and regional expenditure variables have been grouped into the first factor, while the participation rate and employment rate are grouped into the second. The third factor is composed mainly of years of education (see table 13).

Table 13

Rotated component matrix and commonalities (human capital dimension)

\begin{tabular}{lcccc}
\hline \multirow{2}{*}{ Variable } & \multicolumn{3}{c}{ Component } & \multirow{2}{*}{ Commonalities } \\
\cline { 2 - 4 } & 1 & 2 & 3 & 0.958 \\
\hline DE1 & 0.149 & 0.385 & 0.887 & 0.912 \\
\hline DE2 & 0.878 & 0.267 & -0.265 & 0.955 \\
\hline DE3 & 0.151 & 0.945 & 0.198 & 0.949 \\
\hline DE4 & 0.152 & 0.938 & 0.215 & 0.979 \\
\hline DE5 & 0.950 & 0.091 & 0.263 & 0.979 \\
\hline DE6 & 0.950 & 0.100 & 0.260 & \\
\hline
\end{tabular}

Source: Prepared by the authors.

The commonalities of all the variables were in excess of $90.0 \%$.

Thus, the results indicate that the dimensionality of educational capital can be reduced, given the strong correlation between the variables and the direction of their variability.

\section{iii. The tangible dimension}

The tangible dimension was initially constituted by the following variables: concrete roads (DF1), asphalted roads (DF2), gravel roads (DF3), earth roads (DF4), telephone coverage (DF5), Internet coverage (DF6), drinking water coverage (DF7), sewer system coverage (DF8), electricity grid coverage (DF9), educational establishments (DF10), health-care establishments (DF11) and square metres constructed per year plus services (DF12) (see table 14).

The correlation matrix shows a strong relationship between the variables. For example, there is the statistically significant correlation ( $p$-value $<0.001)$ between telephone coverage and Internet coverage and between drinking water coverage and sewer system coverage (see table 14).

For this same reason, Bartlett's test for sphericity is statistically significant (sig. <0.001). However, the Kaiser-Meyer-Olkin index value, at 0.438, is low (see table 15). 
Table 14

Correlation matrix for the tangible dimension

\begin{tabular}{|c|c|c|c|c|c|c|c|c|c|c|c|c|}
\hline Variable & DF1 & DF2 & DF3 & DF4 & DF5 & DF6 & DF7 & DF8 & DF9 & DF10 & DF11 & DF12 \\
\hline DF1 & 1.000 & & & & & & & & & & & \\
\hline DF2 & -0.337 & 1.000 & & & & & & & & & & \\
\hline DF3 & 0.350 & 0.318 & 1.000 & & & & & & & & & \\
\hline DF4 & $-0.442^{* \star}$ & $0.527^{\star \star}$ & 0.209 & 1.000 & & & & & & & & \\
\hline DF5 & 0.123 & 0.159 & -0.188 & -0.291 & 1.000 & & & & & & & \\
\hline DF6 & 0.120 & 0.196 & -0.174 & -0.287 & $0.998^{\star \star \star}$ & 1.000 & & & & & & \\
\hline DF7 & 0.098 & -0.105 & $-0.499^{* *}$ & -0.298 & 0.191 & 0.200 & 1.000 & & & & & \\
\hline DF8 & -0.128 & -0.256 & $-0.620^{* *}$ & 0.049 & 0.244 & 0.241 & $0.591^{* *}$ & 1.000 & & & & \\
\hline DF9 & $-0.664^{\star \star}$ & 0.176 & -0.308 & $0.549^{\star \star}$ & -0.338 & -0.346 & 0.154 & 0.220 & 1.000 & & & \\
\hline DF10 & 0.169 & 0.441 & 0.185 & -0.227 & $0.877^{\star \star \star}$ & $0.894^{* \star \star}$ & -0.053 & -0.130 & -0.426 & 1.000 & & \\
\hline DF11 & 0.191 & $0.543^{* *}$ & 0.350 & -0.127 & $0.788^{\star \star \star}$ & $0.808^{\star \star \star}$ & -0.116 & -0.244 & -0.419 & $0.977^{\star \star \star}$ & 1.000 & \\
\hline DF12 & 0.126 & 0.151 & -0.143 & -0.273 & $0.995^{\star \star \star}$ & $0.991^{\star \star *}$ & 0.099 & 0.196 & -0.365 & $0.888^{\star \star \star}$ & $0.800^{\star \star \star}$ & 1.000 \\
\hline
\end{tabular}

Source: Prepared by the authors.

Note: $\quad{ }^{*} p$-value $<0.01 ;{ }^{* \star} p$-value $<0.05 ;{ }^{* \star *} p$-value $<0.001$.

Table 15

Bartlett's test for sphericity and the Kaiser-Meyer-Olkin coefficient (tangible dimension)

\begin{tabular}{llr}
\hline Kaiser-Meyer-Olkin measure of sampling adequacy & 0.438 \\
\hline Bartlett's test for sphericity & Approximate chi-squared & 260.302 \\
\cline { 2 - 3 } & gl & 66 \\
\cline { 2 - 3 } & Sig. & 0.000 \\
\hline
\end{tabular}

Source: Prepared by the authors.

In this dimension, a selection has been made of four factors that between them account for $89.919 \%$ of the total variance of the dimension. Details will now be given of the values associated with each of the factors individually and the percentage variance between them (see table 16).

Table 16

Explained variance (tangible dimension)

\begin{tabular}{lccccccc}
\hline \multirow{2}{*}{ Component } & \multicolumn{3}{c}{ Initial eigenvalues } & & & \multicolumn{2}{c}{ Sum of squared saturations of rotation } \\
\cline { 2 - 3 } \cline { 7 - 8 } & Total & $\begin{array}{c}\text { Percentage } \\
\text { variance }\end{array}$ & $\begin{array}{c}\text { Cumulative } \\
\text { percentage }\end{array}$ & & Total & $\begin{array}{c}\text { Percentage } \\
\text { variance }\end{array}$ & $\begin{array}{c}\text { Cumulative } \\
\text { percentage }\end{array}$ \\
\hline 1 & 5.040 & 42.001 & 42.001 & & 5.040 & 42.001 & 42.001 \\
\hline 2 & 2.697 & 22.472 & 64.473 & & 2.697 & 22.472 & 64.473 \\
\hline 3 & 2.259 & 18.823 & 83.295 & & 2.259 & 18.823 & 83.295 \\
\hline 4 & 0.795 & 6.623 & 89.919 & & 0.795 & 6.623 & 89.919 \\
\hline 5 & 0.508 & 4.615 & 95.460 & & & & \\
\hline 6 & 0.294 & 2.674 & 98.134 & & & & \\
\hline 8 & 0.149 & 1.352 & 99.486 & & & & \\
\hline 9 & 0.036 & 0.331 & 99.817 & & & & \\
\hline 10 & 0.018 & 0.165 & 99.982 & & & & \\
\hline 11 & 0.002 & 0.016 & 99.998 & & & & \\
\hline
\end{tabular}

Source: Prepared by the authors.

The main variables composing the first factor are telephone coverage, Internet coverage, educational establishments, health-care establishments and square metres constructed per year. The second component centres on the drinking water coverage and sewer system coverage variables. The concrete roads variable is grouped positively into the third factor and the electricity grid coverage variable is grouped negatively. The fourth factor combines the asphalted roads and earth roads variables (see table 17). 
Table 17

Rotated component matrix and commonalities (tangible dimension)

\begin{tabular}{lccccc}
\hline \multirow{2}{*}{ Variable } & \multicolumn{2}{c}{ Component } & \multicolumn{2}{c}{ Commonalities } \\
\cline { 2 - 5 } & 1 & 2 & 3 & 4 & 0.878 \\
\hline DF1 & 0.050 & 0.032 & -0.918 & -0.177 & 0.887 \\
\hline DF2 & 0.310 & -0.144 & -0.157 & 0.864 & 0.877 \\
\hline DF3 & -0.071 & -0.596 & 0.525 & 0.491 & 0.773 \\
\hline DF4 & -0.247 & -0.091 & -0.448 & 0.710 & 0.984 \\
\hline DF5 & 0.970 & 0.183 & 0.030 & -0.090 & 0.993 \\
\hline DF6 & 0.976 & 0.188 & 0.042 & -0.058 & 0.885 \\
\hline DF7 & 0.033 & 0.927 & 0.157 & -0.007 & 0.771 \\
\hline DF8 & 0.076 & 0.826 & -0.242 & -0.155 & 0.800 \\
\hline DF9 & -0.362 & 0.264 & -0.704 & 0.322 & 0.983 \\
\hline DF10 & 0.951 & -0.137 & 0.178 & 0.166 & 0.984 \\
\hline DF11 & 0.883 & -0.218 & 0.243 & 0.314 & 0.974 \\
\hline DF12 & 0.976 & 0.100 & 0.023 & -0.105 &
\end{tabular}

Source: Prepared by the authors.

With these results, and given the strong commonality of the variables represented by the components selected, the inference is that it is possible to reduce the number of variables within the dimension. This can be achieved by representing them in constructs that take account of the thematic concept relating them, or by removing variables that are redundant in respect of the direction of the variability they express.

\section{iv. The economic dimension}

The last dimension analysed was the economic dimension, the initial proposal for which included the following variables: microenterprises (DEc1), small enterprises (DEc2), medium-sized enterprises (DEc3), large enterprises (DEc4), workers in microenterprises (DEc5), workers in small enterprises (DEc6), workers in medium-sized enterprises (DEc7), workers in large enterprises (DEc8) and investments (DEc9).

In this dimension, it can be seen that there is a high degree of correlation between all the variables except the last (DEc9), which does not have significant correlations with the rest (see table 18).

Table 18

Correlation matrix for the economic dimension

\begin{tabular}{|c|c|c|c|c|c|c|c|c|c|}
\hline Variable & DEc1 & DEc2 & DEc3 & DEc4 & DEc5 & DEc6 & DEc7 & $\mathrm{DEC} 8$ & DEc9 \\
\hline DEc1 & 1.000 & & & & & & & & \\
\hline DEc2 & $0.991^{\star \star *}$ & 1.000 & & & & & & & \\
\hline DEc3 & $0.978^{\star \star \star}$ & $0.997^{\star \star \star}$ & 1.000 & & & & & & \\
\hline $\mathrm{DEc} 4$ & $0.964^{\star \star \star}$ & $0.990^{\star \star \star}$ & $0.998^{\star \star \star}$ & 1.000 & & & & & \\
\hline DEc5 & $0.995^{\star \star \star *}$ & $0.995^{\star \star \star *}$ & $0.985^{\star \star \star}$ & $0.975^{\text {*** }}$ & 1.000 & & & & \\
\hline DEc6 & $0.997^{\star \star * *}$ & $0.997^{* \star *}$ & $0.987^{* \star \star}$ & $0.978^{* * *}$ & $0.998^{\star \star *}$ & 1.000 & & & \\
\hline DEc7 & $0.986^{\star \star \star}$ & $0.999^{\star \star \star}$ & $0.998^{\star \star \star}$ & $0.994^{\star \star \star}$ & $0.991^{\star \star \star}$ & $0.994^{\star \star \star}$ & 1.000 & & \\
\hline DEc8 & $0.959^{\star \star \star}$ & $0.987^{\star \star \star}$ & $0.996^{\star \star \star}$ & $0.999^{\star \star \star \star}$ & $0.971^{\star \star \star}$ & $0.975^{\star \star \star}$ & $0.992^{\star \star \star}$ & 1.000 & \\
\hline DEc9 & 0.277 & 0.361 & 0.399 & 0.420 & 0.318 & 0.307 & 0.373 & 0.431 & 1.000 \\
\hline
\end{tabular}

Source: Prepared by the authors.

Note: $\quad{ }^{*} p$-value $<0.01 ;{ }^{\star \star} p$-value $<0.05 ;{ }^{\star \star \star} p$-value $<0.001$.

In turn, Bartlett's test for sphericity and the Kaiser-Meyer-Olkin measure of adequacy indicate the relevance of continuing with the factor analysis and studying the reduction of dimensionality within the dimension (see table 19). 
Table 19

Bartlett's test for sphericity and Kaiser-Meyer-Olkin test (economic dimension)

\begin{tabular}{llr}
\hline Kaiser-Meyer-Olkin measure of sampling adequacy & 0.745 \\
\hline Bartlett's test for sphericity & Approximate chi-squared & 495.949 \\
\cline { 2 - 3 } & gl & 36 \\
\cline { 2 - 3 } & Sig. & 0.000 \\
\hline
\end{tabular}

Source: Prepared by the authors.

In the same way, it can be seen that just two factors explain $99.304 \%$ of total variance in the dimension. The first factor accounts for $89.940 \%$ of total variability and the second for $9.364 \%$ of the remaining variance in the dimension concerned (see table 20).

Table 20

Explained variance (economic dimension)

\begin{tabular}{|c|c|c|c|c|c|c|}
\hline \multirow[b]{2}{*}{ Component } & \multicolumn{3}{|c|}{ Initial eigenvalues } & \multicolumn{3}{|c|}{ Sum of squared saturations of extraction } \\
\hline & Total & $\begin{array}{l}\text { Percentage } \\
\text { variance }\end{array}$ & $\begin{array}{l}\text { Cumulative } \\
\text { percentage }\end{array}$ & Total & $\begin{array}{l}\text { Percentage } \\
\text { variance }\end{array}$ & $\begin{array}{l}\text { Cumulative } \\
\text { percentage }\end{array}$ \\
\hline 1 & 8.095 & 89.940 & 89.940 & 8.095 & 89.940 & 89.940 \\
\hline 2 & 0.843 & 9.364 & 99.304 & 0.843 & 9.364 & 99.304 \\
\hline 3 & 0.055 & 0.616 & 99.920 & & & \\
\hline 4 & 0.004 & 0.048 & 99.968 & & & \\
\hline 5 & 0.002 & 0.021 & 99.989 & & & \\
\hline 6 & 0.000 & 0.005 & 99.994 & & & \\
\hline 7 & 0.000 & 0.004 & 99.999 & & & \\
\hline 8 & 0.000 & 0.001 & 100.000 & & & \\
\hline 9 & 0.000 & 0.000 & 100.000 & & & \\
\hline
\end{tabular}

Source: Prepared by the authors.

Lastly, and as was to be expected given the analysis of the correlation matrix, the first eight variables associated with enterprises are grouped into the first factor, while the second absorbs the investment variable (DEc9). Thus, the conclusion is that the dimension can be explained with two components. The first is a linear combination of the first eight variables, while the variable associated with investment, when modified in another direction, is represented by the second component. The high value of the commonalities should be emphasized. These indicate that practically all the information contained in the variables is encompassed by the factors (see table 21).

Table 21

Rotated component matrix and commonalities (economic dimension)

\begin{tabular}{lccc}
\hline \multirow{2}{*}{ Variable } & \multicolumn{1}{c}{ Component } & Commonalities \\
\cline { 2 - 3 } & 1 & 2 & 0.98 \\
\hline DEc1 & 0.983 & 0.135 & 1.00 \\
\hline$D E c 2$ & 0.978 & 0.209 & 1.00 \\
\hline$D E c 3$ & 0.970 & 0.238 & 0.99 \\
\hline$D E c 4$ & 0.960 & 0.257 & 0.99 \\
\hline$D E c 5$ & 0.982 & 0.160 & 1.00 \\
\hline$D E c 6$ & 0.985 & 0.160 & 1.00 \\
\hline$D E c 8$ & 0.976 & 0.215 & 0.98 \\
\hline$D E c 9$ & 0.957 & 0.263 & 1.00 \\
\hline
\end{tabular}

Source: Prepared by the authors. 


\section{(c) Ranking of variables}

A final validation stage was implemented as a supplement to the multivariate analysis for the reduction of variables and as a form of methodological triangulation enabling qualitative and quantitative technical and theoretical criteria to be integrated. This stage dealt with the weighting of criteria and the ranking of variables on the basis of Saaty's (1980) analytical hierarchy method.

This type of procedure is particularly suitable when decisions have to be made about the selection of particular elements. In this case, the objective of the application was to select a final list of variables, setting out from the definition of particular criteria. The method proposed by Saaty involves establishing a matrix of comparison between pairs of criteria and comparing the importance of each with the rest. The next step is to establish the main vector. This determines the weights, which in turn provide a quantitative measure of the consistency of value judgements between pairs of factors (Saaty, 1980).

Operationally, and in accordance with what the methodology suggests, the procedure included the following stages:

(i) Delineation of the problem:

How can a set of variables be selected to construct a TDI?

(ii) Identification of the objective:

Rank a list of variables for the construction of a TDI by identifying criteria and subcriteria of different kinds.

(iii) Determination of criteria and subcriteria:

The analytic hierarchy methodology was used to establish the criteria and subcriteria described below:

(a) Conceptual criterion: concerns the theoretical and conceptual aspects of the indicator.

- Conceptual definition subcriterion: whether the variable fits the theoretical definition of the dimension.

- Thematic coverage subcriterion: whether the variable is able to encompass some or all of the theoretical definition of the dimension.

(b) Statistical criterion: concerns the methodological and statistical aspects of the indicator.

- Factor analysis subcriterion: whether the variable brings variability to the dimension.

- Comparability subcriterion: whether the variable is present in the different communes and thus comparable.

- Quality subcriterion: whether the variable has the requisite statistical quality at the commune level.

(c) Management criterion: concerns the impact of public policy on changes in the indicator.

- Planning subcriterion: whether the variable may be affected by the operation of territorial plans or programmes.

- Influence-dependency subcriterion: whether the variable exerts a relationship of influence or dependency on other variables (or vice versa) in the polynomial.

(iv) Assessment methodology:

The assessment was carried out on the basis of paired comparisons of criteria and subcriteria. The intention is for the assessor to make a determination of one criterion's importance relative to another. ${ }^{6}$

6 The panel of experts comprises three researchers from the Institute of Local and Regional Development of the University of the Frontier and five analysts from the National Institute of Statistics in the Araucanía region. 
Each comparison of paired criteria was scored. In this case there are more than two scorers (eight in total), so that the final value of each paired combination will be equivalent to the average of the scores awarded by each of the scorers, both at the first hierarchical level (criteria) and at the sublevels (subcriteria).

The next step is to estimate the relative rates of the " $\mathrm{v}$ " criteria on the basis of the scores given in matrix " $A$ ". These relative weights are the particular vectors of matrix $A$. The method is based on the Perron-Frobeniustheorem, whichyieldslocal prioritiesbysolving thefollowingoptimization problem:

$$
\max A v=\lambda v \text { s.a } \sum_{j} j v_{j}=1
$$

(v) The rating scale:

The criteria are evaluated using the scale proposed by Saaty (1980), which has nine rating levels. On this scale, 1 means that $A$ is of the same importance as $B$, and 9 that $A$ is of extreme importance relative to $\mathrm{B}$. Table 22 presents details of the scale values and their definitions.

Table 22

Rating scale for the ranking method used

\begin{tabular}{lll}
\hline Value & Definition & Comments \\
\hline 1 & Equal importance & Criterion A is as important as B. \\
\hline 3 & Moderate importance & Experience and judgment slightly favour criterion A over B. \\
\hline 5 & Strong importance & Experience and judgment strongly favour criterion A over B. \\
\hline 9 & Very strong importance & Criterion A is much more important than B and its dominance is demonstrated in practice. \\
\hline $2,4,6,8$ & Extreme importance & Criterion A is irrefutably more important than B. \\
\hline & Intermediate values expressing shades between the above. \\
\hline
\end{tabular}

Source: Prepared by the authors.

(vi) Results of the rating:

Once the calculations had been carried out and the weights assigned to each of the criteria and subcriteria, the list of variables was ranked. Variables receiving low scores on the criteria assigned were discarded, reducing the model from one with 49 variables to a more restricted one with a total of 19 variables.

\section{Third model adjustment}

Subjecting the model to the different tests and methodologies and reducing as many dimensions as possible led to the identification of six types of capital for measuring the development of a territory. These capital types or dimensions are taken to include the variables that are most important or best explain the dimension. Table 23 describes the third model adjustment with the dimensions and variables needed for the final calculation of the proposed index. 
Table 23

Operationalization of variables matrix

\begin{tabular}{|c|c|c|c|}
\hline Dimension & Variable & Conceptual definition & Operational definition \\
\hline \multirow[t]{4}{*}{$\begin{array}{l}\text { Cultural } \\
\text { capital }\end{array}$} & $\begin{array}{l}\text { 1. Tangible } \\
\text { cultural heritage }\end{array}$ & $\begin{array}{l}\text { Places, sites, buildings, engineering works, industrial centres, architectural } \\
\text { ensembles, heritage areas and monuments of major architectural, } \\
\text { archaeological, historical, artistic or scientific interest or value that are } \\
\text { recognized and registered as such. }\end{array}$ & $\begin{array}{l}\text { Number of heritage assets } \\
\text { recognized by decree, } \\
\text { by commune. }\end{array}$ \\
\hline & $\begin{array}{l}\text { 2. Intangible } \\
\text { cultural heritage }\end{array}$ & $\begin{array}{l}\text { Living traditions or forms of expression inherited from forebears and passed } \\
\text { down to descendants, such as: oral traditions, performing arts, social } \\
\text { customs, rituals, festivities, knowledge and practices relating to nature and } \\
\text { the universe, and techniques and lore related to traditional crafts. }\end{array}$ & $\begin{array}{l}\text { Number of intangible heritage } \\
\text { assets registered in the } \\
\text { Information System for } \\
\text { Heritage Management } \\
\text { (SIGPA), by commune. }\end{array}$ \\
\hline & $\begin{array}{l}\text { 3. Indigenous } \\
\text { communities } \\
\text { and associations }\end{array}$ & $\begin{array}{l}\text { By an indigenous community is meant any group of people belonging to the } \\
\text { same ethnicity who are in one or more of the following situations: (i) they } \\
\text { are from the same family stock; (ii) they recognize a traditional headship; } \\
\text { (iii) they own or have owned indigenous lands in common; (iv) they are from } \\
\text { the same long-standing settlement. By an indigenous association is meant } \\
\text { a voluntary functional grouping of at least } 25 \text { indigenous persons who join } \\
\text { together in pursuit of some common interest and goal. }\end{array}$ & $\begin{array}{l}\text { Number of indigenous } \\
\text { communities and } \\
\text { associations, by commune. }\end{array}$ \\
\hline & $\begin{array}{l}\text { 4. Place brands and } \\
\text { designations of origin }\end{array}$ & $\begin{array}{l}\text { Geographical indications and designations of origin protect products from } \\
\text { the country or from a region or local area, provided they have a quality, } \\
\text { reputation or other characteristic attributable to their geographical origin. }\end{array}$ & $\begin{array}{l}\text { Number of geographical } \\
\text { indications and designations } \\
\text { of origin, by commune. }\end{array}$ \\
\hline \multirow[t]{2}{*}{$\begin{array}{l}\text { Social } \\
\text { capital }\end{array}$} & $\begin{array}{l}\text { 5. Organizations with } \\
\text { social aims }\end{array}$ & $\begin{array}{l}\text { Non-profit public interest organizations whose aim is to further the general } \\
\text { interest, whether in respect of citizen rights, social assistance, education, } \\
\text { health, the environment or any other matter of common interest (parents' } \\
\text { associations, older adult centres or organizations, sports clubs, } \\
\text { neighbourhood committees and other functional groupings). }\end{array}$ & $\begin{array}{l}\text { Number of organizations with } \\
\text { social aims and current legal } \\
\text { personality, by commune. }\end{array}$ \\
\hline & $\begin{array}{l}\text { 6. Electoral } \\
\text { participation }\end{array}$ & $\begin{array}{l}\text { Registered voters (in percentages) participating voluntarily in municipal } \\
\text { elections. }\end{array}$ & $\begin{array}{l}\text { Percentage voting out of total } \\
\text { enrolled, by commune. }\end{array}$ \\
\hline \multirow[t]{3}{*}{$\begin{array}{l}\text { Human } \\
\text { capital }\end{array}$} & 7. Years of education & $\begin{array}{l}\text { Average number of years spent in the education system. Applies to persons } \\
\text { aged } 15 \text { and over. }\end{array}$ & $\begin{array}{l}\text { Average years' education, } \\
\text { by commune. }\end{array}$ \\
\hline & $\begin{array}{l}\text { 8. University } \\
\text { selection tests (PSU) }\end{array}$ & $\begin{array}{l}\text { Average score in the Language and Mathematics university selection } \\
\text { tests (PSU). }\end{array}$ & $\begin{array}{l}\text { Average score in PSU, } \\
\text { by commune. }\end{array}$ \\
\hline & $\begin{array}{l}\text { 9. Professionalization } \\
\text { of municipal } \\
\text { personnel }\end{array}$ & $\begin{array}{l}\text { Human capital with a degree or professional qualification employed } \\
\text { by the municipality. }\end{array}$ & $\begin{array}{l}\text { Percentage of professional } \\
\text { workers employed in the } \\
\text { municipality, by commune. }\end{array}$ \\
\hline \multirow[t]{3}{*}{$\begin{array}{l}\text { Institutional } \\
\text { capital }\end{array}$} & $\begin{array}{l}\text { 10. Dependence } \\
\text { on the Municipal } \\
\text { Common Fund (FCM) }\end{array}$ & $\begin{array}{l}\text { Dependence on the FCM (as the main source of funding) relative to } \\
\text { revenues generated by the municipality itself. The FCM is a needs-based } \\
\text { mechanism for redistributing financial resources between the country's } \\
\text { municipalities with a view to ensuring that they function properly and can } \\
\text { attain their purposes. The FCM was designed to benefit poorer districts, } \\
\text { particularly those with few options for raising permanent revenues of other } \\
\text { kinds for themselves, so that it provides the main source of } \\
\text { municipal revenues. }\end{array}$ & $\begin{array}{l}\text { Percentage of total municipal } \\
\text { revenues provided by the } \\
\text { FCM, by municipality. }\end{array}$ \\
\hline & $\begin{array}{l}\text { 11. Municipal } \\
\text { expenditure }\end{array}$ & $\begin{array}{l}\text { Municipal budget item that includes operating, transfer and investment } \\
\text { spending, the application of third-party revenues and other expenditure, } \\
\text { divided by the population of the commune. }\end{array}$ & $\begin{array}{l}\text { Municipal expenditure } \\
\text { per capita in Chilean pesos, } \\
\text { by municipality. }\end{array}$ \\
\hline & $\begin{array}{l}\text { 12. Municipal } \\
\text { ordinances }\end{array}$ & $\begin{array}{l}\text { Ordinances are binding general regulations applicable to the community. } \\
\text { They might include provision for fines not exceeding five monthly tax units } \\
\text { (UTM), levied by the relevant local police courts. }\end{array}$ & $\begin{array}{l}\text { Number of municipal } \\
\text { ordinances, by commune. }\end{array}$ \\
\hline \multirow[t]{4}{*}{$\begin{array}{l}\text { Tangible } \\
\text { capital }\end{array}$} & 13. Road network & $\begin{array}{l}\text { Concrete roads are made of concrete slabs separated by joints and laid } \\
\text { on a properly compacted granular bed. Asphalt roads are made of jointless } \\
\text { asphalt concrete wearing courses at least } 10 \mathrm{~cm} \text { thick. }\end{array}$ & $\begin{array}{l}\text { Kilometres of concrete roads } \\
\text { and asphalt as a percentage } \\
\text { of all roadways, by commune. }\end{array}$ \\
\hline & $\begin{array}{l}\text { 14. Internet } \\
\text { penetration }\end{array}$ & Share of the population with a fixed-line home Internet connection. & $\begin{array}{l}\text { Percentage Internet coverage, } \\
\text { by commune. }\end{array}$ \\
\hline & $\begin{array}{l}\text { 15. Square metres } \\
\text { constructed }\end{array}$ & $\begin{array}{l}\text { Square metres constructed and officially certified during the year. } \\
\text { Constructions predating the General Buildings and Urbanization act } \\
\text { of May } 1931 \text { are exempt from regularization. }\end{array}$ & $\begin{array}{l}\text { Officially certified buildings as } \\
\text { an estimated percentage of all } \\
\text { buildings in the commune. }\end{array}$ \\
\hline & $\begin{array}{l}\text { 16. Rural drinking } \\
\text { water coverage }\end{array}$ & $\begin{array}{l}\text { Share of the rural population with a drinking water supply in the home or on } \\
\text { the property or access to a public standpipe or hydrant. }\end{array}$ & $\begin{array}{l}\text { Percentage of rural drinking } \\
\text { water coverage, by commune. }\end{array}$ \\
\hline \multirow[t]{3}{*}{$\begin{array}{l}\text { Economic } \\
\text { capital }\end{array}$} & $\begin{array}{l}\text { 17. Workers' } \\
\text { remuneration }\end{array}$ & $\begin{array}{l}\text { Average employee remuneration as reported by the Internal Revenue } \\
\text { Service (SII), estimated from pay levels and the number of workers. }\end{array}$ & $\begin{array}{l}\text { Reported average monthly } \\
\text { wage of employees in Chilean } \\
\text { pesos, by commune. }\end{array}$ \\
\hline & $\begin{array}{l}\text { 18. Investment by } \\
\text { the National Fund } \\
\text { for Regional } \\
\text { Development (FNDR) }\end{array}$ & Implementation of regional investment programmes. & $\begin{array}{l}\text { Annual per capita expenditure } \\
\text { in Chilean pesos, } \\
\text { by commune. }\end{array}$ \\
\hline & 19. Bank loans & $\begin{array}{l}\text { A bank loan is credit in cash that a bank provides to a client, who commits } \\
\text { to repaying it gradually in the future in instalments or in a single payment } \\
\text { with additional interest to compensate the creditor for the time the money } \\
\text { was unavailable. }\end{array}$ & $\begin{array}{l}\text { Number of loans per capita, } \\
\text { by commune. }\end{array}$ \\
\hline
\end{tabular}

Source: Prepared by the authors. 


\section{(a) Weighting of the territorial development index}

The criterion of equal weighting of dimensions was used to assign relative weights to the dimensions and the respective variables within them. The benchmark taken was the criteria used by UNDP/MIDEPLAN (2005) in the allocation of weights for the communal human development index $(\mathrm{HDI})$ and in the new methodology for measuring multidimensional poverty in Chile proposed by the Social Observatory of the Ministry of Social Development. Equal weighting means that the dimensions have the same specific weight within the index and that the same weight is applied to variables within each dimension.

According to Alkire and Foster (2011), the selection of weights can be considered a value judgment, open to public scrutiny. There is no definitive formula for allocating weights. Broadly speaking, however, there are at least two equally valid alternatives: (i) giving each variable the same weight, which might mean the dimensions having different weightings if the number of variables per dimension is different, or (ii) giving each dimension the same weight, which might mean the variables having different weightings if the number of variables per dimension is different. The second option is applied for the proposed index.

According to the premise on which equivalent or equal weighting is based, there are no generally accepted arguments justifying or supporting an allocation of different weights to the different dimensions, or variables, as applicable (Ministry of Social Development, 2013). Where the weighting of attitude scales is concerned, Canales (2006) states that, in the absence of any compelling theoretical or empirical reason to assign a greater weight to one question or another, it is best for them all to have the same weight. Thus, for example, institutional capital can be assumed to play as important a role in this case as tangible or social capital in bringing about territorial development processes.

The TDI proposed in this paper comprises a total of six dimensions (types of capital), so that each dimension will have a weighting of $16.6 \%$. As already indicated, the weighting of each variable will depend on the number of variables per dimension. Table 24 describes the weighting of the index in detail.

Table 24

Structure of weights

\begin{tabular}{|c|c|c|c|}
\hline Capital & $\begin{array}{l}\text { Weight of dimension } \\
\text { (percentages) }\end{array}$ & Variable & $\begin{array}{c}\text { Weight of variable } \\
\text { (percentages) }\end{array}$ \\
\hline \multirow[t]{4}{*}{ 1. Cultural } & \multirow[t]{4}{*}{16.67} & 1. Tangible cultural heritage & \multirow[t]{4}{*}{4.17} \\
\hline & & 2. Intangible cultural heritage & \\
\hline & & 3. Indigenous communities and associations & \\
\hline & & 4. Place brands and designations of origin & \\
\hline \multirow[t]{2}{*}{ 2. Social } & \multirow[t]{2}{*}{16.67} & 5. Organizations with social aims & \multirow[t]{2}{*}{8.33} \\
\hline & & 6. Electoral participation & \\
\hline \multirow[t]{3}{*}{ 3. Human } & \multirow[t]{3}{*}{16.67} & 7. Years of education & \multirow[t]{3}{*}{5.56} \\
\hline & & 8. University selection tests (PSU) & \\
\hline & & 9. Professionalization of municipal personnel & \\
\hline \multirow[t]{3}{*}{ 4. Institutional } & \multirow[t]{3}{*}{16.67} & 10. Dependence on FCM & \multirow[t]{3}{*}{5.56} \\
\hline & & 11. Municipal expenditure & \\
\hline & & 12. Municipal ordinances & \\
\hline \multirow[t]{4}{*}{ 5. Tangible } & \multirow[t]{4}{*}{16.67} & 13. Road network & \multirow[t]{4}{*}{4.17} \\
\hline & & 14. Internet penetration & \\
\hline & & 15. Square metres constructed & \\
\hline & & 16. Rural drinking water coverage & \\
\hline \multirow[t]{3}{*}{ 6. Economic } & \multirow[t]{3}{*}{16.67} & 17. Worker remuneration & \multirow[t]{3}{*}{5.56} \\
\hline & & 18. Investment by FNDR & \\
\hline & & 19. Bank loans & \\
\hline
\end{tabular}

Source: Prepared by the authors. 


\section{(b) Description of the territorial development index}

The territorial development index (TDI) is an indicator that draws together a set of variables which are dissimilar in both scale and units of measurement, grouped into six types of territorial capital. The purpose of these variables is to capture the main phenomena associated with development capacity, taking in not only the economic component but all the aspects that interact in the territory, including cultural, social and human capital.

As already discussed, the development factors incorporated into the measurement are: cultural capital, social capital, human capital, institutional capital, tangible capital and economic capital. Between them, they include a total of 19 variables. As explained in the previous section, each of the factors or capital types concerned is equally weighted, and its load is distributed equally between the variables underpinning each of the dimensions.

In other words, the specific weight of each dimension will be determined by the constant $w=\frac{100}{n}$, in which $n$ is equivalent to the number of dimensions. Meanwhile, the weighting in each dimension will be specified as follows: $\alpha_{i}=\frac{100}{n * m_{i}}$, where $m_{i}$ is the number of variables within the $i$-th dimension $(i=1,2, \ldots, n)$.

Given the diversity of scales of the variables concerned, and in view of the multiple data standardization alternatives, it was decided to apply the maxima and minima method, which was used by UNDP to standardize the HDI. As explained by the UNDP office in Chile, by establishing fixed floors and targets, the logic of normative minimum and maximum values allows each country, region and commune to be compared with itself. This methodology means, for example, that the absolute value of the $\mathrm{HDI}$ of an analysed unit does not depend on the performance of the rest and that it is a useful tool irrespective of any relative comparison (UNDP/MIDEPLAN, 2005). Thus, taking the above into consideration, it was decided to adapt them to a single common range of 0 to 1 .

This is achieved by calculating the ratio between the effective distance and the range of variability for each variable. In other words, the following transformation is adopted for the $j$-th variable:

$$
Z_{j}=\frac{X_{j}-X_{j}^{\min }}{X_{j}^{\max }-X_{j}^{\min }}
$$

Where $X_{j}^{\min }=\min \left(X_{j}^{k}, k=1, \ldots, 342\right)$ and $X_{j}^{\max }=\max \left(X_{j}^{k}, k=1, \ldots, 342\right)$. Lastly, the calculation of the index in each factor takes the following structure:

$$
I_{i}=\alpha_{i} \sum_{j=1}^{m_{i}} Z_{j}
$$

Thus, the general index can be calculated by taking the weighted sum of the indices by factors (equivalently, it is possible to take the sum weighted through the variables). The TDI will be determined by the following functional relationship:

$$
I=w \sum_{i=1}^{n} I_{i}
$$

Thus, the variability range of the indicator is between 0 and 1 . Values closer to 1 denote greater development of the territory while, conversely, values closer to 0 indicate a lower level of development. The factor components highlight the opportunities and potential that can be exploited in them. 


\section{(c) Calculating the territorial development index}

The results of the calculation of the indicator in the communes named, i.e., Angol and Carahue, will now be presented (see table 21).

According to the results of the TDI, the commune of Angol is more highly developed than the commune of Carahue. In numerical terms, Angol has a TDI of 0.280 , while Carahue has a value of 0.232 , giving a development gap of 0.048 points.

This difference can be explained by analysing the results for the territorial capitals. As figure 1 shows, Angol is more highly developed on all the factors measured except economic capital. The greatest differences are in human capital (0.096 points), cultural capital (0.089 points) and tangible capital (0.066 points).

\section{Figure 1}

Territorial development index by dimension, communes of Angol and Carahue

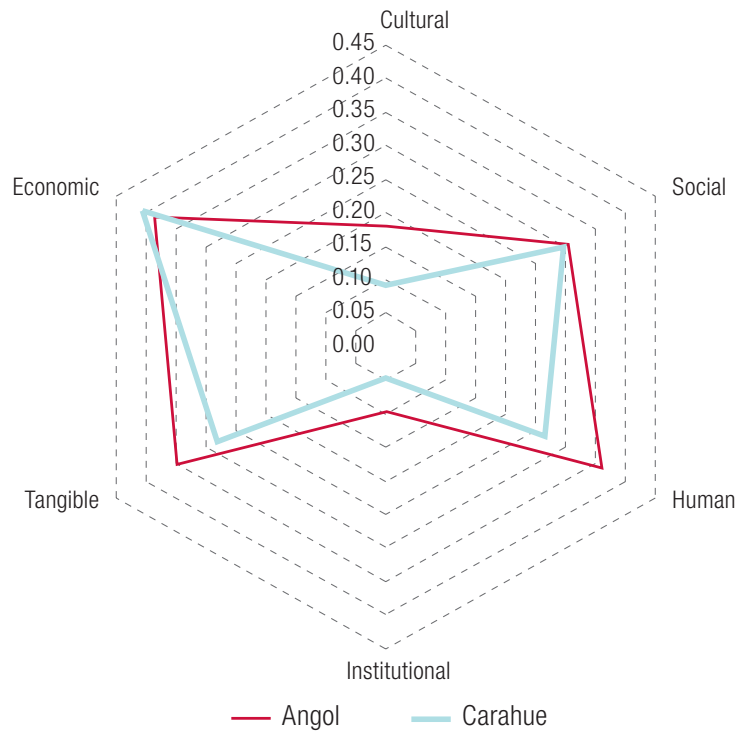

Source: Prepared by the authors on the basis of official statistics.

Angol presents better characteristics than Carahue in the human capital dimension, as it is better positioned on the years of education and PSU variables. However, the commune of Carahue presents a higher percentage of professional municipal personnel.

Regarding cultural capital, the comparative result is defined mainly by the larger number of place brands and of assets registered as intangible cultural heritage in Angol. In the commune of Carahue, these differences are partly offset by the predominance of indigenous communities and of tangible cultural heritage.

Angol again presents a better situation than Carahue where tangible capital is concerned, given that it has greater Internet penetration and a larger surface area of built infrastructure. However, the commune of Carahue has a higher percentage of concrete and asphalt roads in its total communal road network.

The commune of Angol is better placed than Carahue for institutional capital. This is because it is less dependent on the Municipal Common Fund (FCM), per capita municipal spending is higher and there are more municipal ordinances. 
No significant differences are observed between Carahue and Angol where the social capital dimension is concerned because while Carahue has fewer social organizations, participation in municipal elections is greater there (see table 25).

Table 25

Calculation of the territorial development index

\begin{tabular}{|c|c|c|c|c|c|c|c|c|c|}
\hline Capital & Variable & Angol & Carahue & Min. & Max. & ZAngol & ZCarahue & Angol & Carahue \\
\hline \multirow[t]{4}{*}{ Cultural } & 1. Tangible cultural heritage & 6.0 & 32.0 & 0.0 & 190.0 & 0.03 & 0.17 & 0.18 & 0.09 \\
\hline & 2. Intangible cultural heritage & 8.0 & 5.0 & 0.0 & 61.0 & 0.13 & 0.08 & & \\
\hline & $\begin{array}{l}\text { 3. Indigenous communities } \\
\text { and associations }\end{array}$ & 0.7 & 1.4 & 0.0 & 11.8 & 0.06 & 0.11 & & \\
\hline & $\begin{array}{l}\text { 4. Place brands and } \\
\text { designations of origin }\end{array}$ & 1.0 & 0.0 & 0.0 & 2.0 & 0.50 & 0.00 & & \\
\hline \multirow[t]{2}{*}{ Social } & $\begin{array}{l}\text { 5. Organizations with } \\
\text { social aims }\end{array}$ & 692.0 & 148.0 & 0.0 & 4305.0 & 0.16 & 0.03 & 0.30 & 0.30 \\
\hline & 6. Electoral participation & 50.6 & 56.7 & 26.8 & 80.0 & 0.45 & 0.56 & & \\
\hline \multirow[t]{3}{*}{ Human } & 7. Years of education & 10.0 & 8.0 & 7.0 & 16.0 & 0.33 & 0.11 & 0.36 & 0.27 \\
\hline & 8. PSU & 469.8 & 435.6 & 362.4 & 613.5 & 0.43 & 0.29 & & \\
\hline & $\begin{array}{l}\text { 9. Professionalization of } \\
\text { municipal personnel }\end{array}$ & 0.2 & 0.3 & 0.0 & 0.7 & 0.32 & 0.39 & & \\
\hline \multirow[t]{3}{*}{ Institutional } & 10. Dependence on FCM & 0.7 & 0.9 & 1.0 & 0.0 & 0.26 & 0.11 & 0.10 & 0.05 \\
\hline & 11. Municipal expenditure & 191.0 & 180.4 & 65.8 & 10531.1 & 0.01 & 0.01 & & \\
\hline & 12. Municipal ordinances & 16.0 & 13.0 & 2.0 & 609.0 & 0.02 & 0.02 & & \\
\hline \multirow[t]{4}{*}{ Tangible } & 13. Road network & 11.2 & 14.4 & 0.0 & 100.0 & 0.11 & 0.14 & 0.35 & 0.28 \\
\hline & 14. Internet penetration & 22.9 & 7.1 & 0.0 & 100.6 & 0.23 & 0.07 & & \\
\hline & $\begin{array}{l}\text { 15. Square metres } \\
\text { constructed }\end{array}$ & 2.1 & 0.9 & 0.0 & 24.1 & 0.09 & 0.04 & & \\
\hline & $\begin{array}{l}\text { 16. Rural drinking water } \\
\text { coverage }\end{array}$ & 1.0 & 0.9 & 0.0 & 1.0 & 0.97 & 0.88 & & \\
\hline \multirow[t]{3}{*}{ Economic } & 17. Worker remuneration & 185833 & 333223 & 46164 & 1703.167 & 0.39 & 0.55 & 0.39 & 0.41 \\
\hline & 18. Investment by FNDR & 32.1 & 85.9 & 0.0 & 4950.3 & 0.01 & 0.02 & & \\
\hline & 19. Bank loans & 1.8 & 0.2 & 0.0 & 151.2 & 0.77 & 0.66 & & \\
\hline Total & & & & & & & & 0.2802 & 0.2319 \\
\hline
\end{tabular}

Source: Prepared by the authors on the basis of official statistics.

Where economic capital is concerned, lastly, Carahue has better figures than Angol, with higher average worker remuneration and a greater volume of investment devolved by the National Fund for Regional Development (FNDR) because of the major investment projects undertaken in recent times. When it comes to bank lending in the communes, however, Angol presents better figures than Carahue, perhaps because it has a larger bankable population.

\section{Conclusions}

This article is the result of extensive work and long sessions of debate by a multidisciplinary team. For three years, the researchers set themselves to design a development index that would reflect how the application of particular types of capital can give rise to territorial development processes at the local level. To this challenge must be added the difficulties associated with the scarcity of information at the subregional level. This meant an intensive effort of review, systematization and selection of secondary data sources that could provide the model with thematic coverage while meeting criteria of representativeness, comparability and periodicity, among others. This was done for the purpose of providing local operators with a system for measuring development that would be workable enough to be reproduced over time. 
In addition to all the above, there are other elements that reinforce the work done. The close relationship established between the theoretical, analytical and practical levels should be emphasized here. This is a proposal that sets out by creating a theoretical model (of types of territorial capital). This model brings together elements from the different development theories that define the dimensions of the index. The next step is a series of multivariate statistical analyses whose purpose is to make certain adjustments to the model by reducing the dimensionality of the data (and validating the proposal technically) and thence arrive at a simplified calculation of a TDI for the communes of Angol and Carahue on the basis of administrative records.

Also worth stressing is the importance given in this study to logging the research. In other words, rather than simply showing the results of the final calculation of the indicator, an effort has been made to document the different stages and methodological decisions taken to make adjustments in the indicator leading to a (more or less) definitive version. This is important insofar as this practice allows other researchers to acquaint themselves with more internal details of the process, including the procedures involved, the decisions made and the successes and failures. Ultimately, this type of methodological approach serves to foster open debate about how the requisite knowledge is progressively acquired in a particular scientific field.

The ultimate purpose in constructing an indicator of this nature is that it provides an opportunity to generate detailed information for decision-making. The first aim is to diagnose the underlying or structural factors that make development possible. The second is to supply information about variables that can be influenced by public or private policy decisions in order to improve development conditions (from a multidimensional perspective) in this territorial space.

Another substantive contribution are the theoretical approaches associated with the identification of structural factors that define the ability of a territorial space to cope with the complexity of development. The conclusion is that the approach based on types of territorial capital provides a sound basis for building on the analyses undertaken by Alburquerque, Vásquez Barquero, Boisier, Requejo and institutions such as UNDP. This represents a contribution, for example, to the deliberations involved in territorial management policymaking for underdeveloped areas in Chile.

\section{Bibliography}

Alburquerque, F. (2013), "Economía del desarrollo y desarrollo territorial” [online] http://www.conectadel.org/ wp-content/uploads/downloads/2015/03/E\%C2\%AADesarrollo-y-Desarrollo-Territorial-3.01.pdf.

Alkire, S. and J. Foster (2011), "Understandings and misunderstandings of multidimensional poverty measurement", Journal of Economic Inequality, vol. 9, No. 2, Springer.

Boisier, S. (2004), "Una (re)visión heterodoxa del desarrollo (territorial): un imperativo categórico", Estudios Sociales, vol. 12, No. 23, January-June [online] https://dialnet.unirioja.es/descarga/articulo/2108278.pdf.

Canales, M. (2006), Metodologías de investigación social. Introducción a los oficios, Santiago, LOM Ediciones.

Cea D’Ancona, M. A. (2002), Análisis multivariable. Teoría y práctica en la investigación social, Madrid, summary.

Cerda, T. and X. Vera (2008), "Indicadores sociales y marcos conceptuales para la medición social", Working Paper, Santiago, National Institute of Statistics [online] http://historico.ine.cl/canales/sala_prensa/ revistaseconomicas/documentostrabajo/30_06_09/documento_de_trabajo_indicadores_sociales.pdf.

Chile Emprende (2005), Guía metodológica del desarrollo territorial, Santiago [online] http://www.dhl.hegoa. ehu.es/ficheros/0000/0243/Chile_Estrategia_de_desarrollo_econ\%C3\%B3mico_territorial_2009.pdf.

Cuadras, C. M. (2007), Nuevos métodos de análisis mutivariante, Barcelona, CMC Editions [online] http:// www.est.uc3m.es/esp/nueva_docencia/getafe/estadistica/analisis_multivariante/doc_generica/archivos/ metodos.pdf.

ECOSOC (Economic and Social Council) (2011), "Report of France on the measurement of economic performance and social progress" (E/CN.3/2011/35), United Nations [online] https://unstats.un.org/unsd/ statcom/doc11/2011-35-France-E.pdf. 
Figueras, M. (2001), "Análisis de conglomerados o cluster" [online] http://ciberconta.unizar.es/LECCION/ cluster/100.HTM.

Filgueira, F. (2006), "La antipática pero necesaria defensa política de la tecnocracia en América Latina", Evaluación para el desarrollo social: aportes para un debate abierto en América Latina, M. Vera (ed.), Guatemala City, Magna Terra Editores S.A.

García, E., J. Gil and G. Rodríguez (2001), "Análisis factorial", Cuadernos de Estadística, No. 7, Madrid, Editorial Hespérides/Editorial La Muralla.

González, H., O. M. Sánchez and Y. Araúz (2011), "Marco conceptual, metodológico y operativo de la planificación regional: guía metodológica para el diseño de la estrategia de abordaje regional en planificación del desarrollo", Ministry of National Planning and Economic Policy/United Nations Development Programme (UNDP) [online] https://documentos.mideplan.go.cr/alfresco/d/d/workspace/SpacesStore/8c6568608f17-47df-a6e1-67cfccf89dff/CPR-001_1.pdf?guest=true.

Hair, J. F., R. E. Anderson and R. L. Tatham (1987), Multivariate Data Analysis, Macmillan.

Ministry of Social Development (2013), "Procedimiento de cálculo de la tasa de pobreza a nivel comunal mediante la aplicación de metodología de estimación para áreas pequeñas (SAE)", Serie Documentos Metodológicos, No. 1 [online] http://observatorio.ministeriodesarrollosocial.gob.cl/indicadores/docs/ Procedimiento_de_calculo_de_la_Tasa_de_Pobreza_a_nivel_Comunal_11feb13_5118dab432f1c.

OECD (Organization for Economic Cooperation and Development) (2008), Handbook on Constructing Composite Indicators: Methodology and User Guide, Paris [online] http://www.oecd.org/sdd/42495745.pdf.

Presidential Advisory Committee for Decentralization and Regional Development (2014), "Propuesta de política de Estado y agenda para la descentralización y el desarrollo territorial de Chile. Hacia un país desarrollado y justo", Santiago [online] http://www.senado.cl/prontus_senado/site/artic/20141007/ asocfile/20141007112343/descentralizacion_informe.pdf.

Requejo, J. (2007), "Clases de capital territorial. Clases de capital territorial y desarrollo sostenible" [online] http://www.atclave.es/publicaciones/descargas/pub_desarrollo/17_clases_de_capital_territorial.pdf.

Saaty, T. (1980), The Analytic Hierarchy Process, New York, McGraw Hill.

Schuschny, A. and H. Soto (2009), "Guía metodológica: diseño de indicadores compuestos de desarrollo sostenible", Project Documents (LCM.255), Santiago, Economic Commission for Latin America and the Caribbean (ECLAC) [online] http://repositorio.cepal.org/bitstream/handle/11362/3661/1/S2009230_es.pdf.

Toloza, I. (2007), "Desarrollo territorial: un modelo descentralizado de gestión en la región de la Araucanía, Chile", thesis, Austral University of Chile.

UNDP/MIDEPLAN (United Nations Development Programme/Ministry of Planning and Cooperation) (2005), Las trayectorias del desarrollo humano en las comunas de Chile (1994-2003), Santiago [online] http:// desarrollohumano.cl/idh/download/IDHC\%20con\%20portada.pdf.

Vázquez Barquero, A. (2007), "Desarrollo endógeno. Teorías y políticas de desarrollo territorial", Investigaciones Regionales, No. 11, Madrid, Spanish Association of Regional Science [online] http://www.redalyc.org/ pdf/289/28901109.pdf. 


\section{Annex A1}

Table A1.1

Initial identification of variables by dimension

\begin{tabular}{|c|c|}
\hline \multicolumn{2}{|l|}{ Variables identified } \\
\hline \multirow[t]{10}{*}{ Cultural dimension } & 1. Number of lof (clans) \\
\hline & 2. Number of indigenous communities \\
\hline & 3. Number of indigenous associations \\
\hline & 4. Kilometres of indigenous development areas \\
\hline & 5. Number of machis (religious healers) \\
\hline & 6. Number of loncos (heads of clans) \\
\hline & 7. Number of heritage assets \\
\hline & 8. Number of designations of origin \\
\hline & 9. Number of place brands \\
\hline & 10. Number of cultural events \\
\hline \multirow[t]{17}{*}{ Social dimension } & 11. Number of NGOs \\
\hline & 12. Number of neighbourhood committees \\
\hline & 13. Number of community unions \\
\hline & 14. Number of local committees \\
\hline & 15. Number of older adult clubs \\
\hline & 16. Number of youth groups \\
\hline & 17. Number of sporting associations \\
\hline & 18. Number of cultural associations \\
\hline & 19. Number of health-care organizations \\
\hline & 20. Number of women's groups \\
\hline & 21. Number of churches \\
\hline & 22. Number of charitable organizations \\
\hline & 23. Number of cooperatives \\
\hline & 24. Number of employers' associations \\
\hline & 25. Number of craft associations \\
\hline & 26. Number of student centres \\
\hline & 27. Number of political parties or groupings \\
\hline \multirow[t]{7}{*}{ Human capital dimension } & 28. Number of technical and professional workers \\
\hline & 29. Number of postgraduates \\
\hline & 30. Number of students taking university selection tests (PSU) and accepted by universities \\
\hline & 31. Number of professionals from the commune working in other communes \\
\hline & 32. Percentage of population that is of active age \\
\hline & 33. Number of workers by branch of activity \\
\hline & 34. Number of small and medium-sized enterprises \\
\hline \multirow[t]{16}{*}{ Institutional dimension } & 35. Number of business licences \\
\hline & 36. Number of municipal ordinances \\
\hline & 37. Existence of a current Communal Development Plan (PLADECO) \\
\hline & 38. Existence of a current Zoning Plan \\
\hline & 39. Existence of a current Institutional Strategic Plan \\
\hline & 40. Existence of a current Annual Municipal Health Plan (PASAM) \\
\hline & 41. Existence of a current Annual Municipal Education Plan (PADEM) \\
\hline & 42. Existence of a communal geographic information system (GIS) \\
\hline & 43. Kilometres of zones of tourist interest \\
\hline & 44. Number of financial services \\
\hline & 45. Number of training services \\
\hline & 46. Number of health-care platforms \\
\hline & 47. Number of transport platforms \\
\hline & 48. Number of telecommunications platforms \\
\hline & 49. Number of professionals per inhabitant \\
\hline & 50. Number of FNDR projects implemented with a favourable technical recommendation \\
\hline
\end{tabular}


Table A1.1 (concluded)

\begin{tabular}{|c|c|}
\hline \multicolumn{2}{|l|}{ Variables identified } \\
\hline \multirow[t]{5}{*}{ Institutional dimension } & 51. Number of Regional Fund for Local Initiative (FRIL) projects implemented \\
\hline & 52. Number of Urban Improvement Programme (PMU) projects implemented \\
\hline & 53. Autonomous municipal revenue in Chilean pesos \\
\hline & 54. Percentage of budget spent on health \\
\hline & 55. Percentage of budget that depends on the Municipal Common Fund (FCM) \\
\hline \multirow[t]{29}{*}{ Infrastructure dimension } & 56. Number of universal access points \\
\hline & 57. Number of telecentres \\
\hline & 58. Number of information centres \\
\hline & 59. Number of libraries associated with BiblioRedes \\
\hline & 60. Percentage coverage of asphalted road networks \\
\hline & 61. Percentage coverage of surfaced road networks \\
\hline & 62. Number of first aid posts \\
\hline & 63. Number of doctor's surgeries \\
\hline & 64. Number of hospitals \\
\hline & 65. Number of complex care beds \\
\hline & 66. Number of dental chairs \\
\hline & 67. Number of $X$-ray machines \\
\hline & 68. Number of tomography machines \\
\hline & 69. Number of schools \\
\hline & 70. Number of boarding schools \\
\hline & 71. Number of libraries \\
\hline & 72. Percentage housing deficit \\
\hline & 73. Percentage housing materials deficit \\
\hline & 74. Percentage drinking water coverage \\
\hline & 75. Percentage electricity grid coverage \\
\hline & 76. Percentage sewer system coverage \\
\hline & 77. Number of machines for primary production \\
\hline & 78. Kilometres of State-protected wilderness \\
\hline & 79. Kilometres of maritime areas \\
\hline & 80. Kilometres of lake areas \\
\hline & 81. Kilometres of river areas \\
\hline & 82. Presence of volcanos \\
\hline & 83. Presence of metal mining resources \\
\hline & 84. Presence of non-metal resources \\
\hline \multirow[t]{4}{*}{ Economic dimension } & 85. Projected communal investments in Chilean pesos \\
\hline & 86. Square metres constructed \\
\hline & 87. Number of building permits \\
\hline & 88. Exports from the commune in Chilean pesos \\
\hline
\end{tabular}

Source: Prepared by the authors. 


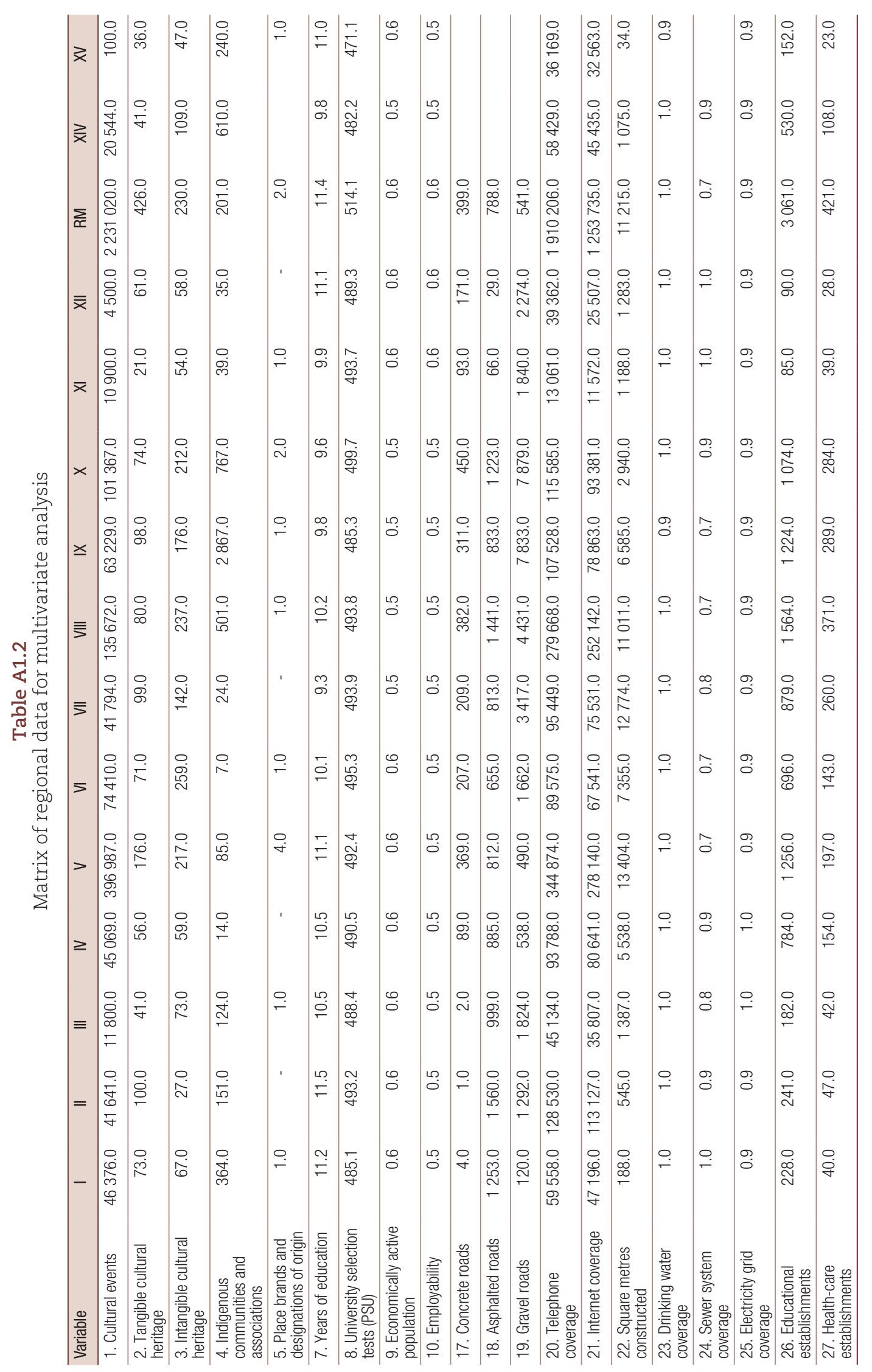




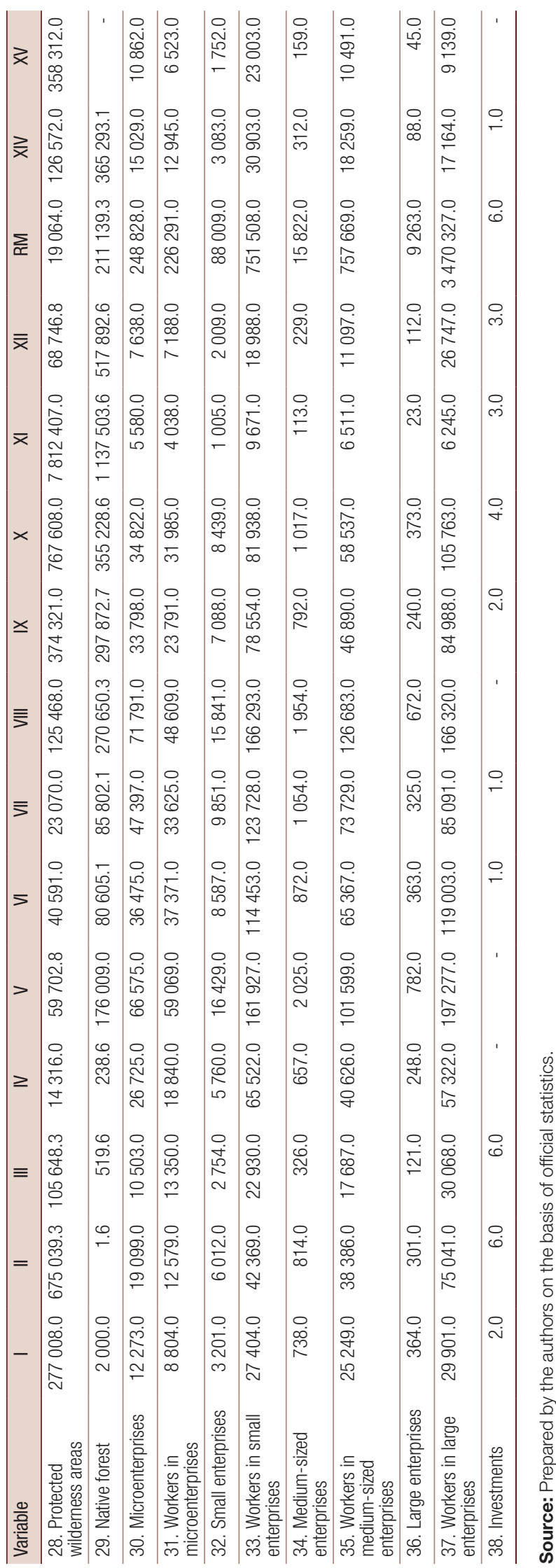

